\title{
Healthcare Risk Management Analysis - A Bibliometric Approach
}

\author{
Ioana Bradea ${ }^{1}$, Camelia Delcea ${ }^{2}$ and Ramona Paun ${ }^{3}$ \\ ${ }^{1,2}$ Bucharest University of Economic Studies, Bucharest, Romania, \\ ${ }^{3}$ Webster University, Bangkok, Thailand \\ Correspondence should be addressed to: Ioana Bradea; alexbradea11304@yahoo.com \\ Received date: 23 February 2015; Accepted date: 8 June 2015; Published date: 17 July 2015 \\ Academic Editor: Catalin Popescu \\ Copyright (C) 2015. Ioana Bradea, Camelia Delcea and Ramona Paun. Distributed under Creative \\ Commons CC-BY 4.0

\begin{abstract}
Using a large-scale dataset from WoS, this paper explores the publications on healthcare risk management, through bibliometric analysis. The bibliometric analysis reflects how research in hospital risk management and healthcare management evolved over time, offering insights on the most relevant and influential research. Based on the idea that researchers publish their most important results in articles, conferences, books and bibliometric analysis reflects the growing interest of research for the area of healthcare risk management. The need to provide high quality medical services requires the design and implementation of a set of key performance indicators for each strategic objective set by the hospital management.
\end{abstract} \\ reviews, there is diffusion in this research field, with many reference countries. The
}

Keywords: hospital risk management, bibliometric indicators, citation analysis, healthcare.

\section{Introduction}

Pritchard Alan (1969), invented the term of bibliometrics, by using it to denote the utilization of mathematical and statistical methods for analysis of written publications. Bibliometrics are used in quantitative research assessment, using key performance indicators for the quality of the research activity. Bibliometrics, or Scientometrics, represents a quantitative analysis method, a statistical technique for journal articles, proceedings papers, reviews, books and their citation counts. The quantitative analysis consists in measuring, recording, computing and analyzing the research results worldwide (Merigo et al., 2015).

The knowledge accumulated over time in the hospital risk management and healthcare fields became more and more complex, requiring new methods and analysis techniques for the decision

Cite this Article as: Ioana Bradea, Camelia Delcea and Ramona Paun (2015), "Healthcare Risk Management Analysis - A Bibliometric Approach", Journal of Eastern Europe Research in Business \& Economics, Vol. 2015 (2015), Article ID 169472, DOI: 10.5171/2015.169472 
making process (Tsay M., 2015). Quality and performance assessment in universities, government and researchers is realised with the help of bibliometrics. According to Fetscherin M., Heinrich D. (2015), the citation counts illustrate the relevance, utility and impact of certain papers, the citation analysis pointing if a paper is in top in a specific area of interest. Bibliometrics are used in different areas of studies, from science and humanities to social sciences.

The data source used is Web of science (WoS) of Thomson\&Reuters. This database includes more than 160.000 papers, from 250 disciplines and visualizes, analyzes and integrates research papers and citation metrics from 1900. It is a reliable database of reference for the university community, including innovative research with a high degree of originality (Delcea, 2014; Cotfas, 2013).

Hospital risk management is a major concern for risk managers to provide better quality in healthcare. Risks that may occur in a hospital are often interconnected, of utmost importance is determining how these risks affect the appearance of other risks. If the hospital is facing more risks, the risk exposure is increasing, causing vulnerability. (Delcea et al., 2014) According to Bradea et al.,
(2014), the risks that affect a hospital can be classified into seven categories, namely: mismanagement risk, inability to engage patients risk, technological risk, hospital conditions risk, human resource risk, clinical risk, cyber security and confidentiality of information risk, inadequate funding risk and regulatory issues risk.

\section{Hospital Risk Management: A Bibliometric Overview}

The WoS database consists in Science Citation Index Expanded (SCIEXPANDED), Social Sciences Citation Index (SSCI), Arts \& Humanities Citation Index (A\&HCI), Conference Proceedings Citation Index- Science (CPCI-S) and Conference Proceedings Citation IndexSocial Science \& Humanities (CPCI-SSH), that register papers originated from 1900.

To develop the search process we have used the keywords: hospital, healthcare and risk and have been provided with the papers related to this field of interest. The search for these three keywords generated 17044 results. After that, there were obtained 65,049 results for hospital risk management and 1192 results for healthcare risk management. 


\begin{tabular}{|c|c|c|}
\hline $\begin{array}{l}\square \text { GENERAL INTERNAL MEDICINE (210) } \\
\nabla \text { HEALTH CARE SCIENCES SERVICES (143) } \\
\nabla \text { INFECTIOUS DISEASES (141) } \\
\nabla \text { PUBLIC ENVIRONMENTAL OCCUPATIONAL HEALTH (125) } \\
\square \text { CARDIOVASCULAR SYSTEM CARDIOLOGY (99) } \\
\square \text { PHARMACOLOGY PHARMACY (83) } \\
\square \text { NURSING (60) } \\
\square \text { SURGERY (55) } \\
\square \text { ENGINEERING (53) } \\
\square \text { RESPIRATORY SYSTEM (42) } \\
\square \text { PEDIATRICS (42) } \\
\square \text { MICROBIOLOGY (36) } \\
\square \text { COMPUTER SCIENCE (33) } \\
\square \text { OBSTETRICS GYNECOLOGY (30) } \\
\square \text { ENVIRONMENTAL SCIENCES ECOLOGY (30) } \\
\square \text { NEUROSCIENCES NEUROLOGY (28) } \\
\square \text { GERIATRICS GERONTOLOGY (28) } \\
\square \text { BUSINESS ECONOMICS (27) } \\
\square \text { MEDICAL INFORMATICS (26) } \\
\square \text { ONCOLOGY (21) } \\
\square \text { IMMUNOLOGY (21) } \\
\square \text { RESEARCH EXPERIMENTAL MEDICINE (20) } \\
\square \text { PSYCHIATRY (20) } \\
\square \text { ENDOCRINOLOGY METABOLISM (19) } \\
\square \text { ANESTHESIOLOGY (19) } \\
\square \text { ORTHOPEDICS (18) } \\
\square \text { GASTROENTEROLOGY HEPATOLOGY (17) } \\
\square \text { UROLOGY NEPHROLOGY (16) } \\
\square \text { OPERATIONS RESEARCH MANAGEMENT SCIENCE (15) }\end{array}$ & $\begin{array}{l}\nabla \text { EMERGENCY MEDIIINE (13) } \\
\square \text { TOXICOLOGY (12) } \\
\square \text { SCIENCE TECHNOLOGY OTHER TOPICS (11) } \\
\square \text { PSYCHOLOGY (11) } \\
\square \text { RHEUMATOLOGY (10) } \\
\square \text { HEMATOLOGY (10) } \\
\square \text { BIOMEDICAL SOCIAL SCIENCES (10) } \\
\square \text { TROPICAL MEDICINE (9) } \\
\square \text { MEDICAL LABORATORY TECHNOLOGY (9) } \\
\square \text { SOCIAL SCIENCES OTHER TOPICS (8) } \\
\square \text { ALLERGY (8) } \\
\square \text { REHABILTATION (7) } \\
\square \text { OTORHINOLARYNGOLOGY (6) } \\
\square \text { OPHTHALMOLOGY (5) } \\
\square \text { NUTRTION DIETETICS (5) } \\
\square \text { DERMATOLOGY (5) } \\
\square \text { WOMEN S STUDIES (4) } \\
\square \text { TRANSPLANTATION (4) } \\
\square \text { INFORMATION SCIENCE LIBRARY SCIENCE (4) } \\
\square \text { SUBSTANCE ABUSE (3) } \\
\square \text { SPORT SCIENCES (3) } \\
\square \text { MEDICAL ETHICS (3) } \\
\square \text { MATHEMATICS (3) } \\
\square \text { MATHEMATICAL COMPUTATIONAL BIOLOGY (3) } \\
\square \text { LIFE SCIENCES BIOMEDICINE OTHER TOPICS (3) } \\
\square \text { EDUCATION EDUCATIONAL RESEARCH (3) } \\
\square \text { WATER RESOURCES (2) } \\
\square \text { SOCIOLOGY (2) }\end{array}$ & $\begin{array}{l}\square \text { SOCIAL ISSUES (2) } \\
\square \text { REPRODUCTNE BIOLOGY (2) } \\
\square \text { RADIOLOGY NUCLEAR MEDIINE MEDICAL IMAGING (2) } \\
\square \text { PATHOLOGY (2) } \\
\square \text { GENETICS HEREDIY (2) } \\
\square \text { FAMLY STUDIES (2) } \\
\square \text { DENTISTRY ORAL SURGERY MEDICINE (2) } \\
\square \text { CONSTRUCTION BULDING TECHNOLOGY (2) } \\
\square \text { CHEMISTRY (2) } \\
\square \text { BIOCHEMISTRY MOLECULAR BIOLOGY (2) } \\
\square \text { VETERINARY SCIENCES (1) } \\
\square \text { THERMODYNAMICS (1) } \\
\square \text { TELECOMMUNICATIONS (1) } \\
\square \text { PUBLIC ADMINISTRATION (1) } \\
\square \text { PHYSIOLOGY (1) } \\
\square \text { PHYSICS (1) } \\
\square \text { PARASTOLOGY (1) } \\
\square \text { NUCLEAR SCIENCE TECHNOLOGY (1) } \\
\square \text { MYCOLOGY (1) } \\
\square \text { MATHEMATICAL METHODS IN SOCIAL SCIENCES (1) } \\
\square \text { MATERIALS SCIENCE (1) }\end{array}$ \\
\hline
\end{tabular}

Figure. 1: The most significant research areas Source: http://thomsonreuters.com/thomson-reuters-web-of-science/

Most articles in this field were written after 2005, before this year only $14 \%$ from total being registered. It can be noticed that the publication number starting from 2005 to 2014 has an increasing trend, with a peak in 2014.

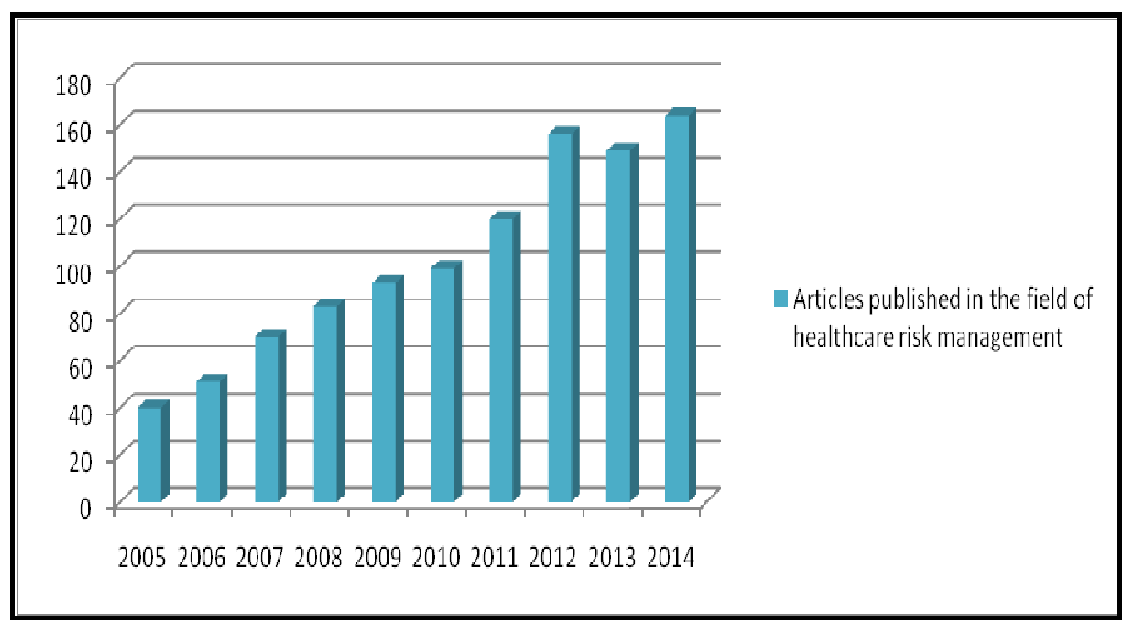

Figure. 2: The evolution of the articles published in the field of healthcare risk management

Source: http://thomsonreuters.com/thomson-reuters-web-of-science/ 
These results classify the information into 85 subject categories and research areas. From these areas of interest were selected the relevant areas for our research that targets the risks that may manifest in a hospital. Thus, after sorting from 1192 results were obtained 550 relevant papers, this bibliometric analysis being focused on the following areas:

Table 1: The research areas of the papers written on healthcare risk management

\begin{tabular}{|l|l|l|}
\hline Research area & $\begin{array}{l}\text { Number of } \\
\text { papers }\end{array}$ & Percent \\
\hline Healthcare sciences services & 143 & 0,26 \\
\hline Infectious diseases & 141 & 0,256364 \\
\hline Public Environmental occupational health & 125 & 0,227273 \\
\hline Nursing & 60 & 0,109091 \\
\hline Surgery & 55 & 0,1 \\
\hline Computer Science & 33 & 0,06 \\
\hline Medical Informatics & 32 & 0,058182 \\
\hline General internal medicine & 30 & 0,054545 \\
\hline Pharmacy & 29 & 0,052727 \\
\hline Business Economics & 27 & 0,049091 \\
\hline
\end{tabular}

\section{Source: http://thomsonreuters.com}

Graphically, the articles are distributed on the research areas as in figure no. 3 . Depending on the language in which they were published, the largest share is obtained by articles published in English
(95.55\%), then were the French articles (1.09\%), Portuguese articles (1.09), German articles $(0.73 \%)$, Italian articles $(0,36 \%)$ and Spanish articles $(0.18 \%)$.

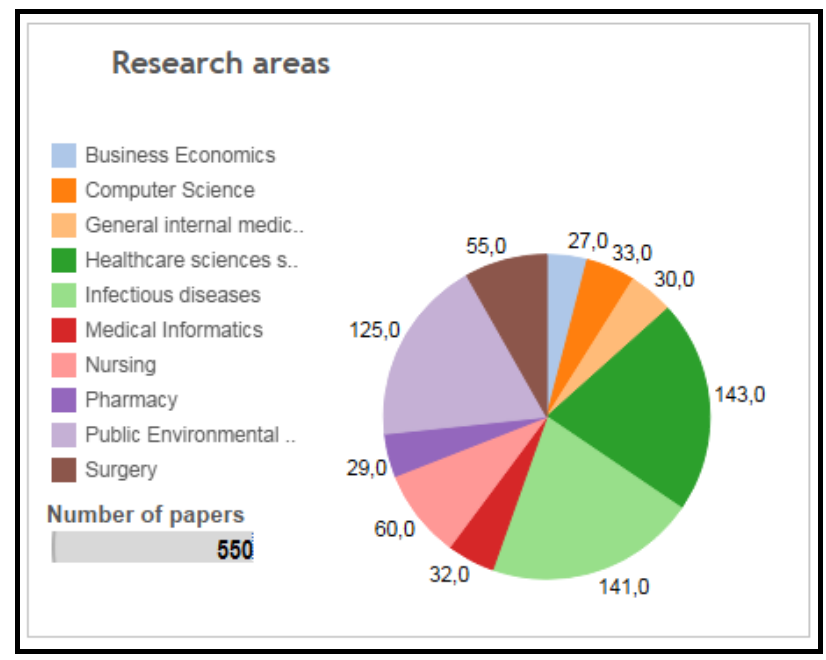

Figure. 3: The percentage of healthcare risk management articles in different research areas Source: http://thomsonreuters.com/thomson-reuters-web-of-science/ 
The year 2013 represents the apogee in terms of interest for this domain, with 78 published papers, representing 13,46\% from the total. For the other years the percents were: 2005 (3,82\%), 2006
(3.82\%), $2007(6,18 \%), 2008(7,64 \%)$, $2009(8,36 \%), \quad 2010 \quad(9,64 \%), \quad 2011$ $(10,73 \%), \quad 2012 \quad(10,55 \%), \quad 2013$ (13,46\%), 2014 (10,18\%).

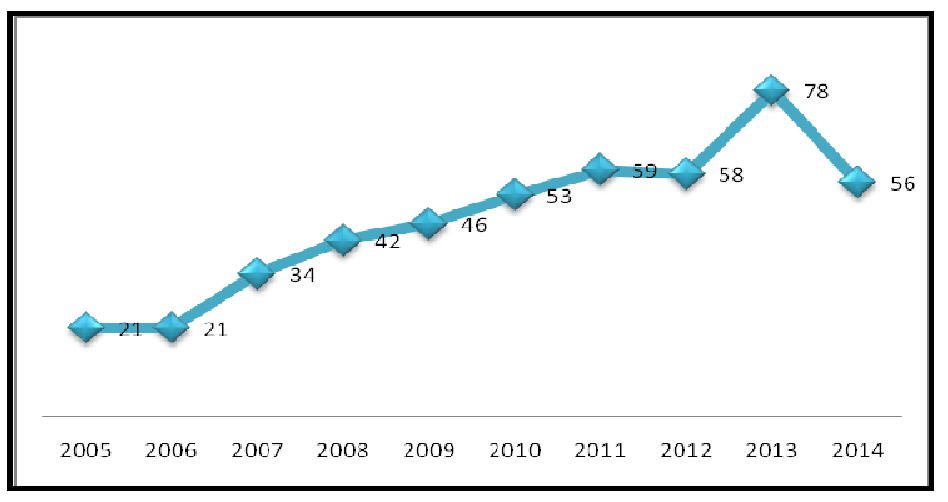

Figure. 4: Number of published papers according to year Source: http://thomsonreuters.com/thomson-reuters-web-of-science/

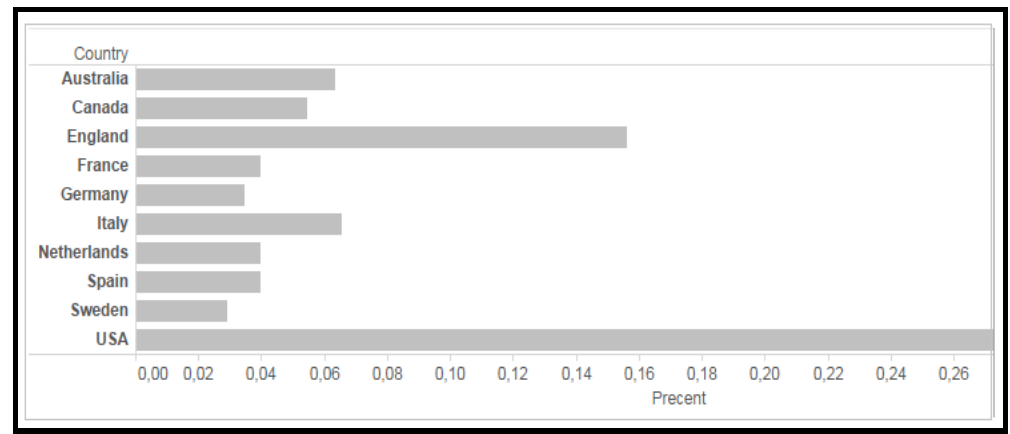

Figure. 5: Country of origin for the recorded papers Source: http://thomsonreuters.com/thomson-reuters-web-of-science/

In terms of geographical distribution of the authors, the most papers were from the United States of America (32.91\%), followed by England (15.64\%), Italy
(6.55\%), Australia (6.36\%), Canada (5.46\%), France (4\%), Netherlands (4\%), Spain (4\%), Germany (3.46\%) and Sweden $(2.91 \%)$. 


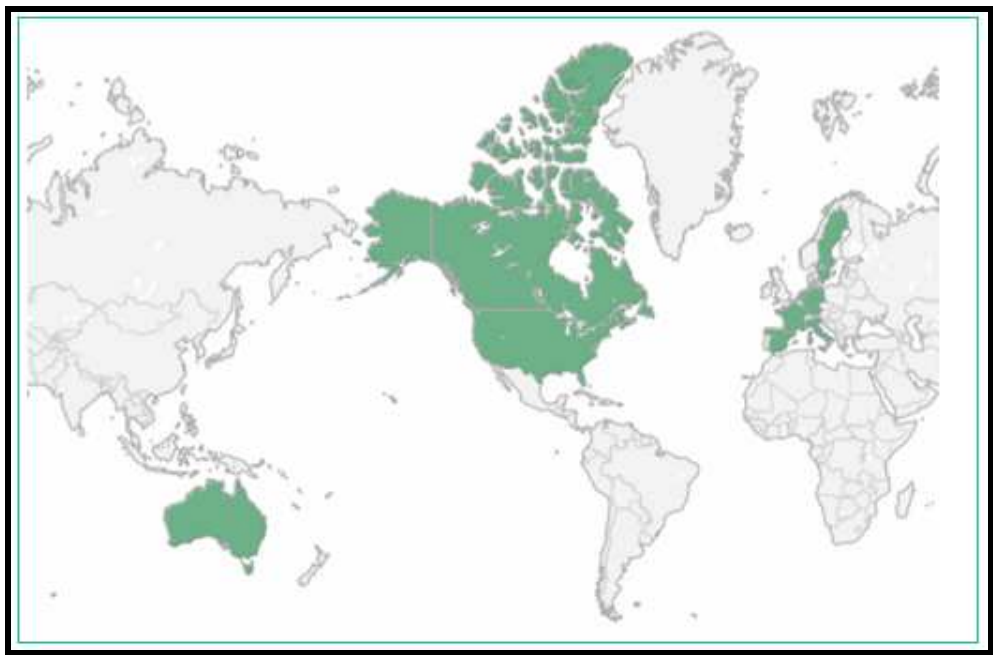

Figure. 6: Country of origin for the recorded papers - A global overview Source: http://thomsonreuters.com/thomson-reuters-web-of-science/

Figure no. 7 presents the classification of recorded papers on healthcare risk management. Over $83 \%$ of these articles are published in ISI journals, followed by articles published in conferences proceedings $(11.46 \%)$. The reviews represent around $10 \%$ of the total papers and the editorial materials account less than $1 \%$.

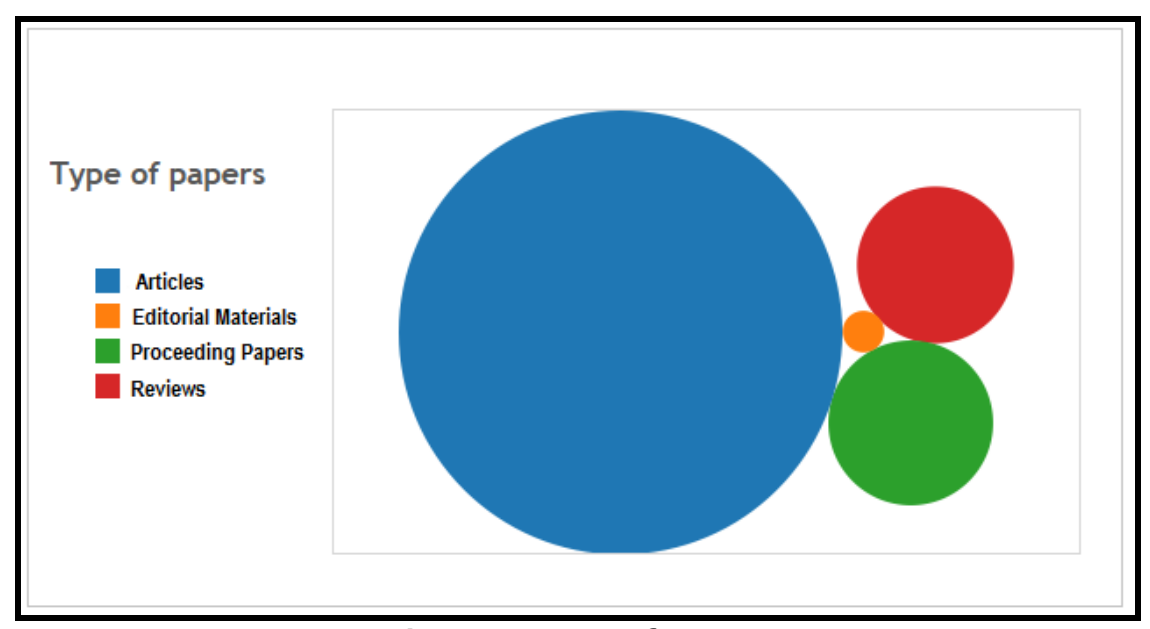

Figure. 7: Type of papers

Source: http://thomsonreuters.com/thomson-reuters-web-of-science/

\section{Citation Analysis}

One of the most known and used method of bibliometrics, citation analysis identifies the frequency, patterns and diagrams in scientific papers. The results obtained through citation analysis are statistically notable due to the quantity of data collection. The following table illustrates the different types of citations found in WoS. 
Table 2: The citation analysis

\begin{tabular}{|l|l|}
\hline Results found & 550 \\
\hline Sum of the Times Cited & 5473 \\
\hline $\begin{array}{l}\text { Sum of Times Cited without self- } \\
\text { citations }\end{array}$ & 5419 \\
\hline Citing Articles & 5223 \\
\hline Citing Articles without self-citations & 5176 \\
\hline Average Citation per Item & 9,95 \\
\hline H Index & 35 \\
\hline
\end{tabular}

Source: http://thomsonreuters.com/thomson-reuters-web-of-science/

The $\mathrm{h}$-index is a measure of the citation impact, illustrates the importance of a set of papers. The H-index is a measure for the distribution of citations received by a paper. The value of 35 indicates that 35 papers from a sample have 35 citations.

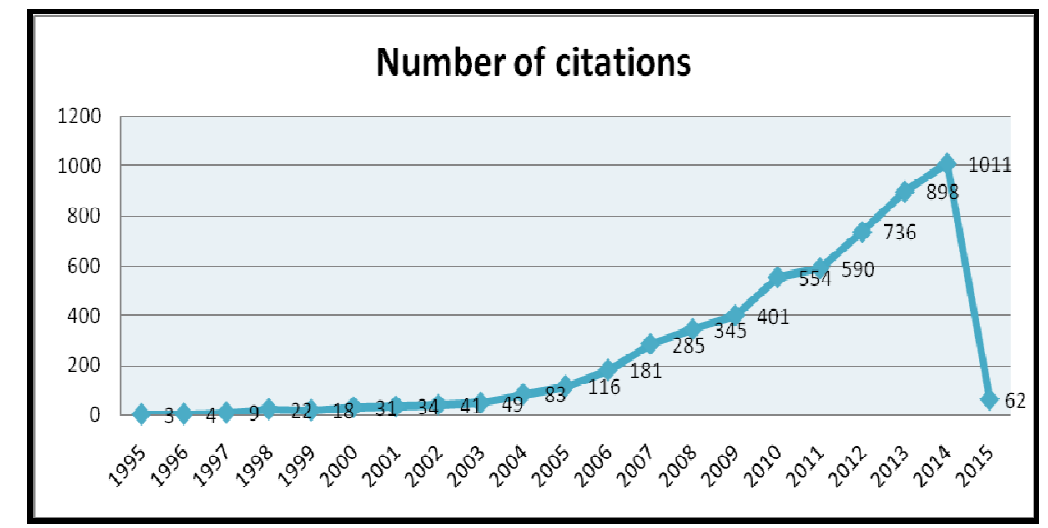

Fig. 8: Number of citations

Source: http://thomsonreuters.com/thomson-reuters-web-of-science/

Analyzing the number of citations for healthcare risk management papers, for the period 1995-20143 it can be easily seen an upward trend, supported by the increased interest in healthcare and risk management. Because for 2015 are recorded papers until February; there is a decrease in the number of citations.
There were recorded 5473 citations and an average of 9,95 citation per paper. The most relevant article on this research area has 184 citations and 15,33 citations per year. There are 30 articles that have the value of the citation per year above 5 . The most relevant papers are presented in the following table. 
Table 3: The papers on healthcare risk management

\begin{tabular}{|c|c|c|c|c|c|}
\hline No. & Title & Authors & Year & $\begin{array}{l}\text { Total } \\
\text { citations }\end{array}$ & $\begin{array}{l}\text { Citations } \\
\text { per year }\end{array}$ \\
\hline 1 & $\begin{array}{l}\text { Systems approaches to surgical quality } \\
\text { and safety - From concept to } \\
\text { measurement }\end{array}$ & $\begin{array}{l}\text { Vincent C., Moorthy K., } \\
\text { Sarker S.K.et al. }\end{array}$ & 2004 & 184 & 15,33 \\
\hline 2 & $\begin{array}{l}\text { Rapid response to stroke symptoms: } \\
\text { The Delay in Accessing Stroke } \\
\text { Healthcare (DASH) study }\end{array}$ & $\begin{array}{l}\text { Rosamond W.D., Gorton } \\
\text { R.A. Hinn A.R. et al. }\end{array}$ & 1998 & 105 & 5,83 \\
\hline 3 & $\begin{array}{l}\text { Guidelines for UK practice for the } \\
\text { diagnosis and management of } \\
\text { methicillin-resistant Staphylococcus } \\
\text { aureus (MRSA) infections presenting in } \\
\text { the community }\end{array}$ & $\begin{array}{l}\text { Nathwani D., Morgan M., } \\
\text { Masterton R.G., et al. }\end{array}$ & 2008 & 96 & 12 \\
\hline 4 & $\begin{array}{l}\text { An outbreak due to multiresistant } \\
\text { Acinetobacter baumannii a burn unit: } \\
\text { Risk factors for acquisition and } \\
\text { management }\end{array}$ & $\begin{array}{l}\text { Simor A.E., Vearncombe } \\
\text { M., Jones-Paul L. et al. }\end{array}$ & 2002 & 89 & 6,36 \\
\hline 5 & $\begin{array}{l}\text { A review of sharps injuries and } \\
\text { preventative strategies }\end{array}$ & Trim J.C., Elliott T.S.J. & 2003 & 83 & 6,38 \\
\hline 6 & $\begin{array}{l}\text { Surgical site infections: epidemiology, } \\
\text { microbiology and prevention }\end{array}$ & Owens C.D., Stoessel K. & 2008 & 72 & 9 \\
\hline 7 & $\begin{array}{l}\text { Prior pneumococcal vaccination is } \\
\text { associated with reduced death, } \\
\text { complications, and length of stay among } \\
\text { hospitalized adults with community- } \\
\text { acquired pneumonia }\end{array}$ & $\begin{array}{l}\text { Fisman D.N., Abrutyn E., } \\
\text { Spaude K.A., et al. }\end{array}$ & 2006 & 71 & 7,1 \\
\hline 8 & $\begin{array}{l}\text { Role of healthcare workers in outbreaks } \\
\text { of methicillin-resistant Staphylococcus } \\
\text { aureus: A } 10 \text {-year evaluation from a } \\
\text { Dutch University Hospital }\end{array}$ & $\begin{array}{l}\text { Blok H.E.M., Troelstra A., } \\
\text { Kamp-Hopmans T.E.M., et } \\
\text { al. }\end{array}$ & 2003 & 68 & 5,23 \\
\hline 9 & Nosocomial influenza in children & $\begin{array}{l}\text { Maltezou H.C., Drancourt } \\
\text { M. }\end{array}$ & 2003 & 62 & 4,77 \\
\hline 10 & $\begin{array}{l}\text { Pressure ulcers and their treatment and } \\
\text { effects on quality of life: hospital } \\
\text { inpatient perspectives }\end{array}$ & $\begin{array}{l}\text { Spilsbury K., Nelson A., } \\
\text { Cullum N., et al. }\end{array}$ & 2007 & 59 & 6,56 \\
\hline 11 & $\begin{array}{l}\text { Systematic review of antimicrobial drug } \\
\text { prescribing in hospitals }\end{array}$ & $\begin{array}{l}\text { Davey P., Brown E., } \\
\text { Fenelon L., et al. }\end{array}$ & 2006 & 59 & 5,9 \\
\hline 12 & $\begin{array}{l}\text { Management of outbreaks of } \\
\text { methicillin-resistant } \\
\text { aureus infection in the neonatal } \\
\text { intensive care unit: A consensus }\end{array}$ & $\begin{array}{l}\text { Gerber S.I., Jones } \\
\text { Roderick C., Scott M.V., et } \\
\text { al. }\end{array}$ & 2006 & 54 & 5,4 \\
\hline
\end{tabular}




\begin{tabular}{|c|c|c|c|c|c|}
\hline & statement & & & & \\
\hline 13 & $\begin{array}{l}\text { Managing Expert Knowledge: } \\
\text { Organizational Challenges and } \\
\text { Managerial Futures for the UK Medical } \\
\text { Profession }\end{array}$ & Waring J., Currie G. & 2009 & 53 & 7,57 \\
\hline 14 & $\begin{array}{l}\text { Feedback from incident reporting: } \\
\text { information and action to improve } \\
\text { patient safety }\end{array}$ & $\begin{array}{l}\text { Benn J., Koutantji M., } \\
\text { Wallace L., et al. }\end{array}$ & 2009 & 53 & 7,57 \\
\hline 15 & $\begin{array}{l}\text { Surgical adverse events, risk } \\
\text { management, and malpractice outcome: } \\
\text { Morbidity and mortality review is not } \\
\text { enough }\end{array}$ & $\begin{array}{l}\text { Morris J.A., Carrillo Y., } \\
\text { Jenkins J.M., et al. }\end{array}$ & 2003 & 51 & 3,92 \\
\hline 16 & $\begin{array}{l}\text { Treatment of multidrug resistant } \\
\text { Acinetobacter }\end{array}$ & $\begin{array}{l}\text { Murray C.K., Hospenthal } \\
\text { D.R. }\end{array}$ & 2005 & 50 & 4,55 \\
\hline 17 & $\begin{array}{l}\text { Severe falciparum malaria in Gabonese } \\
\text { children: clinical and laboratory } \\
\text { features }\end{array}$ & $\begin{array}{l}\text { Dzeing-Ella A., Obiang } \\
\text { P.C.N., Tchoua R. et al. }\end{array}$ & 2005 & 46 & 4,18 \\
\hline 18 & $\begin{array}{l}\text { Laboratory tools and strategies for } \\
\text { methicillin-resistant Staphylococcus } \\
\text { aureus screening, surveillance and } \\
\text { typing: state of the art and unmet needs }\end{array}$ & $\begin{array}{l}\text { Struelens M.J., Hawkey } \\
\text { P.M., French G.L., et al. }\end{array}$ & 2009 & 45 & 6,43 \\
\hline 19 & $\begin{array}{l}\text { Epidemiologic, clinical, and economic } \\
\text { evaluation of an outbreak of clonal } \\
\text { multidrug-resistant Acinetobacter } \\
\text { baumannii infection in a surgical } \\
\text { intensive care unit }\end{array}$ & $\begin{array}{l}\text { Young L.S., Sabel A.L., } \\
\text { Price C.S. }\end{array}$ & 2007 & 44 & 4,89 \\
\hline 20 & $\begin{array}{l}\text { Going solid": a model of system } \\
\text { dynamics and consequences for patient } \\
\text { safety }\end{array}$ & Cook R., Rasmussen J. & 2005 & 44 & 4 \\
\hline 21 & $\begin{array}{l}\text { The comparative medical costs of } \\
\text { atherothrombotic disease in European } \\
\text { countries }\end{array}$ & Levy E., Gabriel S., Dinet J. & 2003 & 43 & 3,31 \\
\hline 22 & $\begin{array}{l}\text { Management of healthcare workers } \\
\text { infected with hepatitis B virus, hepatitis } \\
\mathrm{C} \text { virus, human immunodeficiency virus, } \\
\text { or other bloodborne pathogens }\end{array}$ & $\begin{array}{l}\text { Henderson D.K., Chiarello } \\
\text { L.A., Dickinson G.M., et al. }\end{array}$ & 1997 & 43 & 2,26 \\
\hline 23 & $\begin{array}{l}\text { Country-to-Country Transfer of Patients } \\
\text { and the Risk of Multi-Resistant Bacterial } \\
\text { Infection }\end{array}$ & $\begin{array}{l}\text { Rogers B.A., Aminzadeh } \\
\text { Z., Hayashi Y., et al. }\end{array}$ & 2011 & 42 & 8,4 \\
\hline 24 & $\begin{array}{l}\text { Nanocrystalline silver dressings as an } \\
\text { efficient anti-MRSA barrier: a new } \\
\text { solution to an increasing problem }\end{array}$ & $\begin{array}{l}\text { Strohal R., Schelling M., } \\
\text { Takacs M., et al. }\end{array}$ & 2005 & 41 & 3,73 \\
\hline
\end{tabular}




\begin{tabular}{|c|c|c|c|c|c|}
\hline 25 & $\begin{array}{l}\text { Extended-spectrum beta-lactamase- } \\
\text { producing Gram-negative pathogens in } \\
\text { community-acquired urinary tract } \\
\text { infections: an increasing challenge for } \\
\text { antimicrobial }\end{array}$ & $\begin{array}{l}\text { Meier S., Weber R., } \\
\text { Zbinden R., et al. }\end{array}$ & 2011 & 40 & 8 \\
\hline 26 & $\begin{array}{l}\text { The dilemma of patient responsibility } \\
\text { for lifestyle change: Perceptions among } \\
\text { primary care physicians and nurses }\end{array}$ & $\begin{array}{l}\text { Jallinoja P., Absetz P., } \\
\text { Kuronen R., et al. }\end{array}$ & 2007 & 40 & 4,44 \\
\hline 27 & $\begin{array}{l}\text { Elevated Preoperative Hemoglobin A1c } \\
\text { Level is Associated With Reduced Long- } \\
\text { Term Survival After Coronary Artery } \\
\text { Bypass Surgery }\end{array}$ & $\begin{array}{l}\text { Halkos M.E., Lattouf O.M., } \\
\text { Puskas J.D., et al. }\end{array}$ & 2008 & 38 & 4,75 \\
\hline 28 & $\begin{array}{l}\text { Primary prevention of latex related } \\
\text { sensitisation and occupational asthma: } \\
\text { a systematic review }\end{array}$ & $\begin{array}{l}\text { LaMontagne A.D., Radi S., } \\
\text { Elder D.S., et al. }\end{array}$ & 2006 & 38 & 3,8 \\
\hline 29 & $\begin{array}{l}\text { Community-Associated Extended- } \\
\text { Spectrum beta-Lactamase-Producing } \\
\text { Escherichia } \\
\text { coli Infection in the United States }\end{array}$ & $\begin{array}{l}\text { Doi Y., Park Y.S., Rivera } \\
\text { J.I., et al. }\end{array}$ & 2013 & 37 & 12,33 \\
\hline 30 & $\begin{array}{l}\text { Trends in healthcare incident reporting } \\
\text { and relationship to safety and quality } \\
\text { data in acute hospitals: results from the } \\
\text { National Reporting and Learning } \\
\text { System }\end{array}$ & $\begin{array}{l}\text { Hutchinson A., Young } \\
\text { T.A., Cooper K.L., et al. }\end{array}$ & 2009 & 37 & 5,29 \\
\hline
\end{tabular}

\section{Source: http://thomsonreuters.com/thomson-reuters-web-of-science/}

\section{Concluding Remarks}

Using a large-scale dataset from WoS, this paper explores the publications on healthcare risk management, through bibliometric analysis. The bibliometric analysis reflects how research in hospital risk management and healthcare management evolved over time, offering insights on the most relevant and influential research. Based on the idea that researchers publish their most important results in articles, conferences, books and reviews, there is diffusion in this research field, with many reference countries.

The bibliometric analysis reflects the growing interest of research for the area of healthcare risk management. The need to provide high quality medical services requires the design and implementation of a set of key performance indicators for each strategic objective set by the hospital management.

\section{Acknowledgment}

This paper was co-financed from the European Social Fund, through the Sectorial Operational Programme Human Resources Development 2007-2013, project number POSDRU/159/1.5/S/ 138907 "Excellence in scientific interdisciplinary research, doctoral and postdoctoral, in the economic, social and medical fields -EXCELIS", coordinator The Bucharest University of Economic. Also, 
this work was co-financed from the Studies European Social Fund through Sectoral Operational Programme Human Resources Development 2007-2013, project number

POSDRU/159/1.5/S/134197

„Performance and excellence in doctoral and postdoctoral research in Romanian economics science domain".

\section{References}

1. Bradea, IA., Delcea, C., Scarlat, E. and Boloș, M. (2014), ,'KRIs in Hospitals Network, Correlations and Influences', Economic Computation and Economic Cybernetics Studies and Research, 1/2014, vol. 48, pp. 81-94, ISSN: 0424-267X, http://ecocyb.ase.ro/Articles20141.htm

2. Cotfas, L.A., (2013), „A finitedimensional quantum model for the stock market", Physica A: Statistical Mechanics and its Applications, vol. 392, no. 2, pp. 371-380.

3. Delcea, C., (2014), „Not Black. Not even White. Definitively Grey Economic Systems", The Journal of Grey System, vol. 26 , issue 1, pp. 11-25.

4. Delcea, C., Cotfas, L., Paun, R., (2014), „Grey social networks - a Facebook case study", Proceedings of the 6th International Conference on Computational Collective Intelligence
Technologies and Applications, Lecture Notes in Computer Science, Springer, pp. 125-134.

5. Fetscherin M., Heinrich D., ,Consumer brand relationships research: A bibliometric citation meta-analysis', Journal of Business Research, Elsevier, no. 68, 2015, pp. 380-390

6. Liu W., Tang L., Gu M., Hu G., , Feature report on China: a bibliometric analysis of China-related articles', Scientometrics, vol. 102, 2015, pp. 503-517

7. Merigo J.M., Gil-Lafuente A.M., Yager R.R., ,An overview of fuzzy research with bibliometric indicators', Applied Soft Computing, Elsevier, no. 27, 2015, pp. 420-433

8. Pritchard A., ,Statistical Bibliography or Bibliometrics ?', Journal of Documentation, no. 25, issue 4, 1969, pp.348-349

9. Tsay M., ,Knowledge flow out of the domain of information science: a bibliometric and citation analysis study', Scientometrics, vol. 102, 2015, pp.487502

10. Web of Science, WoS (2015), www.webofknowledge.com - accessed in February 2015. 